\title{
Innovations Creation Process: CEO and Board of Directors Roles
}

\author{
Mariia Evdokimova \\ PhD student, National Research University Higher School of Economics, Moscow, Russia, \\ msevdokimova@hse.ru, ORCID
}

\section{Abstract}

There are innovation creation process, innovations' classifications, and measures considered in the paper. Recently focus on the literature moving from innovations relationship with financials to the role of people. This review considers board of directors group characteristics and CEO individual characteristics (the part of which impacts only firms from innovative industries) significant for innovation creation. The paper predicts investment in innovation, innovation outcome, and optimal for shareholders' wealth board of directors' type in dependence on CEO individual characteristics.

Keywords: innovations, corporate governance, behavioral finance

For citation: Evdokimova, M. Innovations Creation Process: CEO and Board of Directors Roles. Korporativnye finansy = Journal of Corporate Finance Research.2021;15(4):88-101. doi: https://doi.org/10.17323/j.jcfr.2073-0438.15.4.2021.88101 


\section{Introduction about innovation creation process}

What is innovation? The famous Austrian scientist, Josef Schumpeter, coined the term "innovation" in the 1930s and defined it as "new combinations" [1, p. 89]. The author suggested the next innovation process order: invention, innovation, diffusion, and imitation. As we can see from this sequence, the invention differs from innovation, and it is important for the current paper topic because it is devoted to innovation creation. Maclaurin (1953) [2] developed Schumpeter's innovation creation process by adding 'propensities': the propensity to invent, the propensity to innovate, the propensity to finance innovation, and the propensity to adopt innovations. Many authors later used these terms in researches [3-7]. Also, the term propensity to imitate is in use (Singh, 2006) [5].

Companies' innovative activities have a significant impact on the long-term development of the world economy. It requires investments that lead to the development of financial markets, increases the level of competitiveness that impacts consumers welfare, and drives the technological development of the world. Stimuli for companies to innovate are the opportunity of extra-profit receiving. Schumpeter considered profit as a risk premium, however, Knight (1921) [8] thought that profit exists due to uncertainty. But there are some problems with profit receiving from innovations. The thing is that in comparison with the trading business there is a much higher loss probability in innovation activity. An important role in innovation creation plays people, especially those of them who have significant decision-making power such as top managers and members of the board of directors [9-10]. Thus, studying their personal characteristics is useful, both for science and the companies investing in innovations.

Considering board members' and top managers' innovativeness we should look at the innovation creation process at the individual level. According to Schweizer (2006) [11], there is some type of mess in the literature regarding different innovation terms such as innovativeness, novelty-seeking, creativity, and innovative performance. To order terms, she suggested the novelty generation model (NGM). The starting point in the model is the "need for cognition", which is converted to novelty seeking (Figure 1).

Figure 1. The key idea of the novelty generation model (NGM)

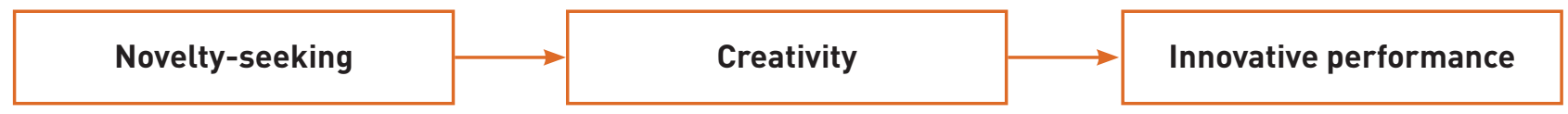

Source: [11].

Schweizer (2006) [11] used the term "novelty seeking" based on information that 'novelty-seeking genes' gens were found: "DRD4, DRD2-A2, SLC6A3-9" [12-14]. Novelty seeking is often considered as a concept relevant to the need to seek out new information, and to exploratory activity in response to novel stimulation [15]. But there is also another concept called 'sensation-seeking' developed by Zuckerman et al. [16-19]. He defined sensation seeking as: "...a trait defined by the seeking of varied, novel, complex, and intense sensations and experiences, and the willingness to take physical, social, legal, and financial risks for the sake of such experience" [17, p. 26]. According to these 2 definitions, we can conclude that the term sensation seeking is wider and includes novelty-seeking.

The second step in the model is "creativity". Schweizer (2006) [11] divided it into novelty-finding and novelty-producing. Creativity according to Yagolkovskiy (2019) [20] is the ability to create new. According to Schweizer (2006) [11], creativity depends on 3 main traits: low levels of cortical and frontal-lobe activation [21], associative capabilities [22], and latent inhibition - the ability to keep many things on the mind at the same time [23]. West (2002) [24] and Cropley et al. (2011) [25] agree that an innovative process includes not only the generation of new ideas but also their possible modification and subsequent application, which are taken into the model as the third step - innovative performance. Schweizer (2006) [11] highlighted the main determinants of innovative performance: achievements need, self-confidence, perseverance, assertiveness, proactivity, extraversion, and cooperativeness. Many authors used these components in the research as explanatory variables for innovations [6, p. 26-27]. Interesting that Nambisan et al. (1998) [3] in their research about IT users' propensity to innovate also highlighted almost the same three components of innovativeness: technology cognizance, ability to explore, and intention to explore a technology.

Also, there is a lot of literature about innovations from technological, marketing, micro, and macro points of view [28]. Moreover, the branch of literature considered the collaborative effect on innovation is quite popular [29; 30]. Authors showed the importance of communication between people with opposite backgrounds for the creation and development of new ideas, for the invention step according to Schumpeter [1], and creativity according to Schweizer (2006) [11]. However, it was proven by Coskun et al. (2000) [31], that group creativity is higher when the group consists of 2-3 members, and the group loses its efficiency with an increase in the number of participants. So, the highest innovation output can be reached in the case of numerous contacts with people from different backgrounds developing an idea, and subsequent work in small teams to bring it to production.

The literature review consists of four main parts: 1) classification and measurement of innovation, 2) the board of directors' role in innovation creation; 3 ) the CEO impact on innovations; 4) influence of the relationship between the CEO and the board on innovations. 


\section{Classification and measurement of innovation}

Before moving to the board and the CEO roles in innovations' creation it is important to overview how innovations are classified and how innovations' input and output can be measured to be able to discuss innovations' efficiency.

There are some classifications of innovation. Damanpour (1996) [32] highlights 4 dimensions of innovation: administrative and technical, product and process, radical and incremental, initiation and implementation [33]. Administrative innovations relate to human resources, technical to the technologies. Rogers (2010) [34] and Zaltman et al. (1973) [35] classification for the initiation of innovation and implementation looks like not types of innovation, but different stages in the innovation creation process considered earlier. Product and process, radical and incremental classifications are more widespread than others [36; 37]. Radical innovations which are also called disruptive, lead to fundamental changes in firm activity and contain a high degree of new knowledge [38; 39]. Incremental innovations refer to a small knowledge increase [38; 40]. This classification is close to the division of innovations on exploratory (when a firm creates new technological knowledge in comparison with the existing one) and exploitative (when technological knowledge was created from existing knowledge) [41]. There is also the term innovations 'ambidexterity' used in the literature that reflects organizational ability to manage both types of innovations [42].

Utterback and Abernathy (1975) [43] were one of the first who used product and process innovations classifications. Product innovation is "the commercialization of new goods or services to meet an external user need" [37, p. 306]. Process innovation is "the introduction into the organization's production process or service operations of new elements" [32, p. 698]. Product and process innovation classification was used in numerous studies [36; 37; 44-47]. Relatively recently this classification was modified by adding business model innovations by Amit and Zott (2012) [48]. The business model innovation changes firms' value creation channels [37]. This wider innovations' classification gathers popularity in research and was used, for example, in Johnson et al. (2008) [49], Crossan and Apaydin (2010) [50], Foss and Saebi (2017) [51], Snihur and Wiklund (2019) [37]. Also, innovations may be classified according to implementation areas: technological, administrative, marketing, etc.

There are two ways how a company can get innovative technologies: develop them by themselves or acquire them from outside [27]. This paper concentrates on the development of innovations inside a company. The most common method of innovation input measurement is the amount of research and development expenditure (R\&D) - so-called $\mathrm{R} \& \mathrm{D}$ intensity, which is usually calculated as " $\mathrm{R} \& \mathrm{D}$ to total sales", "R\&D per employee" or R\&D-to-market equity (R\&D/ME) [52-56]. However, there is a problem with R\&D recognition from an accounting point of view. According to IFRS (IAS 38) [57] expenditure can be recognized as $\mathrm{R} \& \mathrm{D}$ and capitalized only in cases when it can be proved that this expenditure will bring profit in the future. Also, firms are more interested not in investment in innovations, but in their outcomes. So, there is a necessity to evaluate it. There is a methodology to estimate innovations' output as the share of innovation product sales to total sales [58]. The main deficiency of this approach is the unavailability of data about innovative product sales. This information may be received only using survey methodology. Also, scientists use a number of patents and patent citations that may be scaled on R\&D expenditures, the number of employees involved in R\&D activity [59], or R\&D capital [53] to measure innovations outcome $[60 ; 61]$. However, this approach also has a disadvantage: it does not take into account the fact that patents have different values for a company (is this innovation radical or incremental?). That is why the patents' value "weighted" approach [62] is considered as the best measurement for innovation outcome nowadays.

There is also a problem with an accounting of R\&D accumulated, so-called R\&D capital, and especially with its depreciation. Lev et al. (2005) [63] noticed that "companies with a high $\mathrm{R} \& \mathrm{D}$ growth rate relative to their profitability (typically early life-cycle companies) report conservatively, while firms with a low R\&D growth rate (mature companies) tend to report aggressively" [63, p. 977]. And found "undervaluation of conservatively reporting firms and overvaluation of aggressively reporting firms" [63, p. 977]

Chan et al. (2001) [52] and Lev et al. (2005) [63] suggested the next way of R\&D capital estimation: the 5-year cumulative $R \& D$ expenses assuming an annual depreciation rate of $20 \%$

$$
\begin{aligned}
& R \& \text { DCapital }_{i, t}=R \& D_{i, t}+0,8 \cdot R \& D_{i, t-1}+ \\
& +0,6 \cdot R \& D_{i, t-2}+0,4 \cdot R \& D_{i, t-3}+0,2 \cdot R \& D_{i, t-4} \text {. }
\end{aligned}
$$

This approach was used in some studies [53]. R\&D capital depreciation rate is a separate question studied by many authors [64-66]. Recently Li and Hall (2020) [67] suggested a non-linear approach to R\&D capital amortization and found that "the rates are in general higher than the traditionally assumed 15 percent and vary across industries" [67, p. 161].

Also, as R\&D expenditures are exogenously dependent on past years' financial results its estimation requires the usage of instrumented variables [27]. Laursen et al. (2012) [27] used current ratio (CA/CL), equity - noncurrent assets, and gearing ratio (owner's equity over-borrowed funds) as instrumental variables for RD intensity. For external R\&D acquired they used membership of a commercial consortium, labor flexibility (number employees on short-term contracts over the total number of employees), and gearing ratio as instruments.

Considered innovations measurements were used in 2 main branches of study: determinants of innovation input and estimation of innovations output and effectiveness [53; 6869]. In 21 century these researches were extended by including additional variables, for example, intellectual capital [7] (13 359 documents in Scopus) and corporate governance characteristics [9; 53; 61] (27 797 documents in Scopus). 
Figure 2. Cumulative citations in Scopus about CEO, board, and innovations in 2016-2020

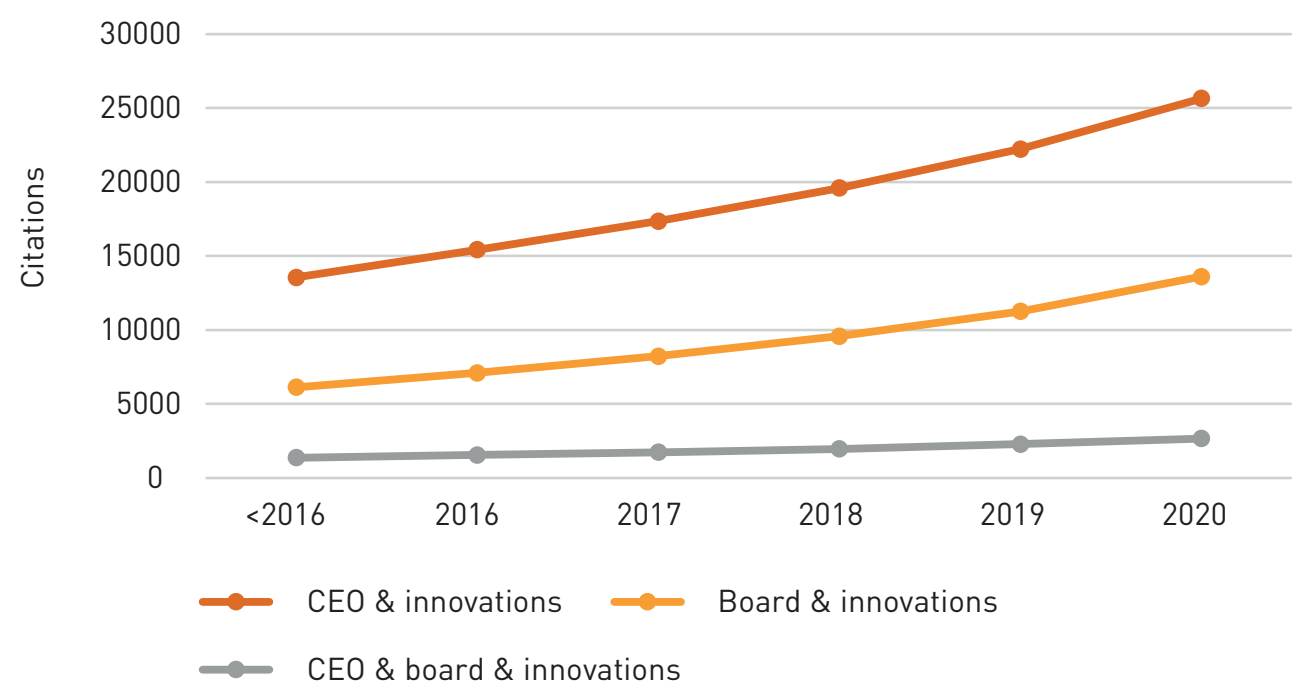

Source: Scopus database search.

Especially scientists are interested in the CEO role in the innovation creation process. Figure 2 represents cumulative citations in Scopus in management and economics during 2016-2020 (Figure 2).

In this paper board of directors' group characteristics and CEO personal characteristics significant for innovations are considered.

\section{Board role}

Only the board of directors' characteristics relates to the board as the group of people will be discussed in this section as individual characteristics considered in the first and next sections may be applied for every board member.

External directors are historically considered as stabilizers and people who are responsible for corruption prevention in the company [70]. However, how do they impact innovations? From the first point of view, they bring a lot of information into the company, including information about recent innovations [71]. Balsmeier et al. (2014) [72] and Helmers et al. (2017) [73], highlighted the importance of independent and cross-board directors for R\&D investment growth and the number of patents. But, from another point of view, external directors' "stabilization function" prevents them from risky investment in innovations [74; 75] in comparison with internal directors. Balsmeier et al. (2017) [70] found that companies with a higher percentage of external directors on the board are concentrated on innovations in some technological areas in which they already had some success. It leads to an increase in citations, but the numbers of uncited and highly cited patents remain at the same level, which confirms the idea about independent directors' risk-aversion. Womens' presence on the board is traditionally considered as a source of gender diversity that, as every diversity should increase creativity [76] and, as an instrument for a reduction in risk appetite [77]. However, some recent studies, for example, Adams \& Ragunathan's paper "Lehman Sisters" (2017) [78], show that women in top management careers should be less risk-averse than men, so it's difficult to predict the direction of their impact on a firm's risk-perception level and innovations.

The board size role in innovation creation processes is still not identified clearly. On the one hand, the larger the board the more information and resources it has to manage. As proven by Mednick (1962) [22] information diversification increases creativity and an opportunity to create innovation consequently. On the other hand, there is an opinion that large boards are less efficient, due to the necessity to spend more time for negotiation [79], and do not have any significant impact on patents' creation [71]. Another debatable board of directors' characteristic is the number of board meetings per year. According to Vafeas' (1999) [80] study, more frequent board meetings make the board more efficient in the long term, but this is caused, usually, by a bad state of affairs, at some stage in the company. However, Chen (2012) [79] did not find any significant relationship between the frequency of board meetings and R\&D.

Regarding board tenure, we can also anticipate two factors. On the one hand, according to Ben Amar et al. (2013) [81], the longer tenure, the easier board members can make decisions, but, on the other hand, they lose their independence and there is a smaller number of new idea sources which can come to the company and push innovations. So, according to Bravo \& Reguera Alvarado (2017) [55] study, there is no relationship between board tenure and R\&D intensity. Numerous authors noticed the important roles of board members' education and work experience for innovation creation. For example, according to Chen (2012) [79], board members' education increases R\&D investment, due to a higher ability to understand and manage complex, innovative projects. Also, it was shown in $\mathrm{Al}-$ lemand et al. study (2017) [10], that if board members have scientific degrees, engineering education, marketing, and research experience, a firms' innovation activity is higher. Sun et al. (2020) [82] proved that a higher level of a firms' human capital correlates with a greater number of patents. 
CEO duality is a quite widespread phenomenon, when the CEO simultaneously acts as the Chairman of the Board. $\mathrm{CEO}$ duality has positive and negative effects. Classically, CEO duality is considered as an unfavorable factor for shareholders' wealth [54]. CEO duality reduces the board's opportunity to control R\&D expenditure to an efficient level [83]. According to Li \& Yang (2019) [84], "CEO tenure is positively related to the percentage of exploitative innovation" [84, p. 539]. In the next block of the literature review, it will be considered in detail, how and why CEO personality is so important for innovation.

\section{CEO role}

The CEO is often considered as the face of the firm, and his or her actions highly impact company strategy and organization at all levels. That is why CEO individual characteristics and experience are very important for a company's investment in innovations and its output, both in the form of patents and citations, and in the form of financial indicators $[60 ; 85 ; 86]$. Later in the text, CEO characteristics-affected innovations are considered in three dimensions: 1 ) innovativeness, 2) risk preferences, 3 ) overconfidence (including mitigation of negative effects).

\section{CEO innovativeness}

Islam and Zein, from Australia, in their article "Inventor CEOs" (2020) [61], studied the CEO propensity to innovate, measured as the number of patents belonging to the CEO. They divided the sample from S\&P 1,500 high tech innovative companies, from 1993 to 2005, for five main categories: active inventor $\mathrm{CEO}$, passive inventor $\mathrm{CEO}$, non-inventor $\mathrm{CEO}$, high-impact inventor $\mathrm{CEO}$, and low-impact inventor $\mathrm{CEO}$. The Active $\mathrm{CEO}$ is a $\mathrm{CEO}$ whose number of patents increased after becoming CEO, passive CEOs received all their patents before becoming CEO. The CEO with the highest number of patents in the sample is Steve Jobs, with 222 patents. The high-impact inventor CEO is a CEO who holds 2 or more highly cited patents.

The authors found a positive correlation between CEO's propensity to innovate and innovations in the company [61]. However, there are 2 possible explanations: 1) An innovative company recognizes its potential and invites an inventor CEO type; 2) The Inventor CEO plays a key role and increases company innovations. To resolve an endogeneity problem authors used a difference in difference model and found that inventor CEO replacement for non-inventor leads to a decrease in the number of patents by $20 \%$ and citations by $36 \%$ [61]. The authors concluded that CEO individuality is more important than a firm's innovative opportunities [61]. Also, they found that the inventor CEO invests in innovations more than the non-inventor, and that the founder effect, CEO overconfidence, and general managerial skills don't incur any significant impact on innovations [61].

Another important part of the research of the "Inventor CEOs" [61] is devoted to CEO experience. According to empirical results, there is a positive correlation between
CEO experience in some technology classes and the number of firm's patents in the same technology class. And the more active the inventor CEO, the higher number of firm patents in the CEO-experienced-technologically class. Moreover, patents from the CEO-experienced-technologically class are more valuable: " $\$ 10.6$ million higher average value per patent" [61, p. 516]. And the probability to create a radical patent in a class is higher when the CEO has "inclass inventor experience" [61, p. 516]. However, the authors found that investing in different technological classes leads to a lower number of patents in each class [61].

Following Mukherjee et al. (2017) [87], Islam and Zein (2020) [61] tested inventor CEO impact on firm financial outcomes and found that the stock market reacts more positively to announcements about a breakthrough new product made by the inventor CEO. Using different propensity to innovate measurement, the authors found that active and high-impact inventor CEOs are associated with a $70 \%$ higher number of patents, citation, and patents value than non-inventor CEOs. Bostan and Mian (2019) [88], also proved that companies, under the direction of inventor CEOs, have a higher number of both cited and uncited patents. It is interesting, also, that, according to the research results, the stock market undervalued inventor CEO-run companies, which allowed the firm to have abnormal stock returns during the first years after the appointment of the inventor CEO.

There is a widespread opinion that management education and work experience also impact his or her behavioral specificities, like risk-preferences and overconfidence [89]. According to Custódio et al. (2019) [90] research, CEOs who have management experience, will lead to an increase in the number of patents, however, some authors suggest that research experience will be the most valuable for CEOs in innovative companies [89]. The question about education consists of two parts: quality and specialization. Gottesman \& Morey (2006) [91], found that the quality of education doesn't affect any significant impact on future innovation activity, including having an MBA degree. Islam and Zein (2020) [61] found that age doesn't incur any impact, however other authors, such as Acemoglu et al. (2014) [92], wrote that age is an important factor. I can suggest a possible explanation: maybe age is correlated with inventor CEO experience, measured as the number of patents, because the older the person is, the more years he or she has to create more patents.

\section{CEO risk-preference}

One of the first relationships between risk and creativity was found by the psychologist. Martindale (1999) [21], who demonstrated that creativity is positively correlated with cortical activation (arousal), which has an inverse U-shape form. When the complexity of the task increases, optimal arousal decreases. More simple tasks require a higher level of arousal. In other words, stress reduces creativity. The same result was observed by Kandasamy et al. (2014) [93], that in stress situations, the cortisol level increases, which reduces risk-appetite. 
On the contrary, Eisenman (1987) [94] was one of the first who claimed about the positive correlation between creativity and risk-taking, studying firstborn white males. Subsequent authors supported Eisenman's point of view [95] and developed it, especially regarding intrinsic motivation [96; 97]. The solution to this contradiction, according to Loch (2017) [98] and Shen et al. (2018) [99], is that risk-taking is a prerequisite of creativity. It means that inventors are ready to take some degree of risk, due to the high expected value of the innovations created, both for society and for themselves.

It is interesting, in the context of the current study, how to measure top-management risk preferences? One recent breakthrough research was made by Sunder et al. (2017) [9]. The authors investigated the presence of CEO pilot licenses as a proxy for sensation seeking. It is important to note that sensation seeking slightly differs from risk attitude and represents openness to new ideas, which is positively correlated with innovativeness [100]. It was found that a lower risk-aversion is positively correlated with innovations' output. Grinblatt \& Keloharju (2009) [101] found that people with a higher number of speeding tickets may be considered as sensation seekers and they are more active on the stock exchange.

There are also investigations devoted to risk perception proxy, like Fischer et al. (2007) [102]. It was proven that online racing games increase the probability of car accidents in real life and risk level in other actions. Also, a positive correlation between extreme sports and risk-taking was found by Self et al. (2007) [103]. However, Brymer (2010) [104] has the opposite view. The author thinks that extreme sportsmen understand risks quite well, both extreme sport risks and everyday risks (e.g. driving a car), they prepared carefully to eliminate the probability of a negative outcome from doing extreme sports, and should not be considered as sensation seekers. It should also be noted that risk is subjective - a motorcyclists' speed may seem excessive to a car driver, but not to another, experienced motorcyclist.

Another factor that impacted risk attitude is "early life exposure to fatal disasters" [105, p. 169] according to Bernile et al. (2017) [105] study. The authors showed that there is a positive relationship between firm risk level and CEO risk attitude formed through negative events in childhood. It is interesting that, if the effects from an early life disaster were low to moderate, a person becomes riskier in the future in the CEO role. At the same time, if a disaster led to dramatic negative consequences, a person chooses a conservative risk minimization strategy in the CEO role. Moreover, Serfling (2014) [106] and Brooks et al. (2018) [107] showed that older investors have higher risk-aversion and lower willingness to invest.

One more interesting research is devoted to the cultural role in risk perception. Frijns et al. (2013) [108] studying M\&A practice across the world, noticed that companies from counties with high risk-aversion, avoid international and cross-industry deals and require a higher premium. Thus, we can conclude that there are some different ways to estimate CEO creativity and innovativeness, using one of the considered sensation-seeking or risk-aversion measures.

\section{CEO overconfidence}

According to Griffin and Tversky (1992) [109], overconfident individuals tend to overestimate the net discounted expected payoffs from uncertain endeavors. When the $\mathrm{CEO}$ of the company is overconfident, it leads to both positive and negative effects for the firm. Before detailed overconfidence consequences consideration, let us review some approaches to CEO overconfidence measurement:

1) Stock options in CEO hands "after the vesting period in which an exercise becomes permissible" [60, p. 1459]. Malmendier \& Tate $(2005,2008)$ $[110 ; 111]$ created an options-based methodology, but Hirshleifer et al. (2012) [60] noticed that data inability does not allow researchers to recalculate $67 \%$ of the value in options, in a clear way, because CEO wealth was unknown;

2) Verbal analysis. For verbal analysis, Hirshleifer et al. (2012) [60] used 2 groups of words in the CEO's speech in the press: confident and cautious. CEO was considered as overconfident if the number of confident phrases exceeds the cautious ones each year;

3) One other methodology that is applicable for overconfidence estimation uses debt inflow because overconfident CEOs value equity more than debt. It is based on the idea that overconfident CEOs tend to overinvest, according to Galasso \& Simcoe (2011) [112];

4) Moreover, there is a methodology that allows researchers to track R\&D profitability - through CDSs (credit default swaps) improved by Chang et al. (2019) [113]. This methodology directly relies on debt financing which allows us to connect it with overconfidence measurement.

Also, it's very important that CEO overconfidence does matter only for risky innovation industries and doesn't incur any significant influence both on R\&D amount and a firm's value in other ones $[60 ; 89 ; 112]$. There are also some interesting findings regarding overconfidence. The first one is that companies with overconfident CEOs should have higher costs, in the form of investments, because the CEO believes in a project's success too much and increases its scale. Malmendier and Tate (2005) [110] demonstrate that overconfident CEOs spend more available internal funds on capital expenditures. Chen et al. (2013) [114] concluded that SG\&A decrease is not desirable for overconfident CEOs because they believe in "future growth prospects and SG\&A needs". The second conclusion is that the overconfident CEO prefers external debt financing, instead of shares issuing, to avoid dilution of equity capital as the CEO values it too high and because the overconfident CEO considers external equity financing as costly [115]. And last, but not least, a finding shows that overconfident CEOs may be slightly aggressive in acquisitions which often cause a negative market reaction [116].

It was found that companies with overconfident CEOs have higher stock volatilities and R\&D expenditures which 
leads to higher patents and citations. However, this innovations' activity, unfortunately, does not always increase a company's value $[60 ; 117 ; 118]$. CEO overconfidence leads to an increase in the number of patents and patent citations, but the correlation is lower than 1 . Moreover, only an extremely overconfident CEO can increase a firm's value through increased patents' citations due to "radical" innovation invention.

\section{CEO vs Board of directors}

Another block of literature proves that CEO overconfidence is not the unique company risk and innovations source. Let's not forget about board and decision-making power distribution across board members, CEO, and other top management (for example, CFO). To evaluate risk correctly, it's necessary to consider board members' risk preferences. Leng et al. (2018) [119] proved that large boards can eliminate the negative effects of CEO overconfidence. Moreover, Kolasinski and Li (2013) [116] showed that well-balanced boards of directors can help overconfident CEOs to avoid mistakes during M\&A deals. One more interesting article was written by Wong et al. (2017) [41] about ambidextrous innovation. They found that "an independent board and dedicated institutional ownership mitigate the positive relationship between CEO overconfidence and a firm's ambidextrous imbalance" [41, p. 414]. Leng et al. (2018) [119] found that overconfident CEOs increase the likelihood of bankruptcy, however, larger boards decrease the probability. Li \& Tang (2010) [120] noticed that the presence of independent directors on the board decreases overinvestment caused by CEO overconfidence. Nakano \& Nguyen (2012) [121] think that a large board can outargue the overconfident CEO in the decision-making process. Using a sample consisting of 940 non-financial UK firms, listed on the LSE, and 1,304 CEOs during 2000-2015 years, the authors proved that the risk of failure is higher in firms managed by overconfident CEOs. At the same time just confident - not overconfident CEOs, reduce the probability of bankruptcy.

One more interesting paper about CEO behavioral bias mitigation by the board is written by Banerjee et al. in 2015 [122]. The authors studied whether independent directors on the board can restrain the negative effects caused by CEO overconfidence such as "extreme risk-taking and overinvestment" [122, p. 2813] on the example of the Sarbanes-Oxley Act (SOX), 2002. Based on O'Conor (2002) [123] the authors suggested that Enron's troubles were not overcome in good time because of the "permissive board that exhibited groupthink and inadequate oversight" [122, p. 2813]. According to Graham et al. (2013) [124] "CEOs tend to be more optimistic, and less risk-averse, than the lay population is" [122, p. 2813]. Banerjee et al. (2015) [122] showed that capital expenditures to total assets made by overconfident CEOs decreased after SOX adoption. Also, they found that the process of SOX led to a significant drop, both in systematic and firm-specific risks, for firms with overconfident CEOs, but was it beneficial for shareholders? The authors demonstrated that SOX adoption leads to an increase in shareholders' wealth in companies with overconfident CEOs, instead of "hinder value creation by these CEOs" [122, p. 2815].

The article, "Board composition and CEO power" by Baldenius et al. printed in the "Journal of Financial Economics" in 2014 [125] studied the board of directors and CEO relationship impact on shareholders' wealth. The authors described 2 types of board: 'centralized' when the board makes a decision, and 'delegated' when the board delegates decision-making power to the CEO. Also, the board has 2 functions: to monitor management activity and to advise. It is interesting to note that board members with a financial background prefer to monitor, while former CEOs and people with technology, marketing, and consulting experience are more involved in advising. In general, CEOs prefer delegation instead of advising from the board side. It's noticeable that the authors assumed that the board fully represented shareholders' interests. Using modeling, the authors showed that "the CEO, at times, has incentives to appoint a board that is excessively focused on monitoring" $[125$, p. 64]. This result is surprising, on the one hand, because CEOs are less willing to be monitored, however, it revealed that the monitoring board prefers to delegate decision-making power to the $\mathrm{CEO}$, which increases his power. The second surprising result is that CEOs can make projects more difficult to reinforce themselves as a company's leader. To counter the threat of entrenchment, shareholders nominate more advisor-biased boards instead of monitoring and advising to the same degree. According to the results obtained, "the less biased the CEO, the more the board delegates" and that "to increase shareholders value, CEO bias has to be small".

Story et al. (2015) [126] showed that the relationship between a firm's value and product innovations looks like an inverse U-shape, both in developed (UK) and developing (Ghana) counties. It is interesting that, for the developing country, an increase in access to financial sources leads to higher innovation output, and there is no such relationship in the developed market. It may be explained through a stable supply of the financial market in a developed country. Moreover, firms from a developing country are less able to compete with their competitors under more dynamic market conditions.

Based on the reviewed information we can formulate hypotheses about R\&D amount, innovations types, and optimal for shareholders' wealth board of directors' types in innovative industries in dependence on two CEO characteristics: innovativeness and overconfidence (Table 1). As overconfidence and innovativeness have a stronger impact in innovative industries $[60 ; 61]$ we take it into account. Risk-taking was not considered separately as it is a prerequisite of innovativeness both in form of creativity (inventor $\mathrm{CEO}$ ) and innovative performance (overconfidence) [11; 98; 99]. 
Table 1. R\&D amount, innovation output, and optimal board of directors' type prediction in dependence on CEO characteristics in innovative industries

\begin{tabular}{|c|c|c|c|c|}
\hline $\begin{array}{l}\text { Inventor } \\
\mathrm{CEO}\end{array}$ & Overconfident CEO & R\&D expenditures & $\begin{array}{l}\text { Innovations } \\
\text { output }\end{array}$ & Optimal board type \\
\hline \multirow{2}{*}{ Non-inventor } & Non-overconfident & The lowest & No & Centralized risky board \\
\hline & Overconfident & Low & Incremental & Centralized moderate board \\
\hline \multirow{2}{*}{ Inventor } & Non-overconfident & High & Incremental & Delegated board \\
\hline & Overconfident & The highest & Radical & Centralized conservative board \\
\hline
\end{tabular}

Source: author's hypotheses based on Islam and Zein (2020) [61]; Hirshleifer et al. (2012) [60]; Hirshleifer et al. (2013) [53]; Baldenius et al. (2014) [125].

Inventor CEO is based on Islam and Zein (2020) [61] and may be measured as the presence of CEO patents. On the one hand, the inventor CEO has all the personal traits required for innovations: the need for cognition, creativity, and innovative performance, however, there is a question will he be able to manage employees as managed themself? That is why we considered Inventor CEO as a person who exactly has the need for cognition and creativity [11], so this person will invest more in $\mathrm{R} \& \mathrm{D}$ than a non-inventor [61]. Overconfident CEO is considered as a person able to succeed in innovative performance [11]. Only an inventor overconfident person can make radical innovations [37; $60 ; 61]$. But overconfidence according to the literature also impacts R\&D expenditures $[60 ; 61]$, so for overconfident $\mathrm{CEO}$, it is higher than for non-overconfident both for inventor and non-inventor CEO types.

Optimal board types were chosen based on Baldenius et al. (2014) [125] between delegated and centralized. We add three levels of risk attitude for a centralized board: risk-averse (conservative board), risk-neutral (moderate board), and risk loving (risky board). Inventor non-overconfident CEO was considered as optimal for innovative industry, because based on his innovativeness we can conclude that he is confident (but not overconfident) [11; 124], that's why his innovative performance may be profitable and stable. So, the best board for such a CEO is delegated board that just monitors the results of the firm activity. For inventor overconfident CEO centralized conservative board will be the better bankruptcy risk-reducing agent [67; 120-122]. A moderate board would fruitfully control non-inventor overconfident CEO, because it will mitigate negative overconfidence effects, but will not interfere with the development of the company. And the risky board will compensate non-inventor non-overconfident CEO.

\section{Conclusion}

According to the review prepared innovations are studied in the literature from many points of view. Innovation creation may be on individual [11] and firm levels [1]. Innovations' input is measured as $\mathrm{R} \& \mathrm{D}$ which is connected with firm financials in two ways: firstly, like expenditures, secondly, as investments that may be profitable or not. That is why usually an inverse U-shape relationship between innovations inputs and share prices is tested [56]. R\&D output may be measured as a share of innovative sales, patents and citation, and using patents' value-weighted approach. Successful innovations require not only the financial base but also sufficient human capital in the company at all levels (from developers to the top management and board members) [7]. Big companies have an advantage in innovation creation due to their ability to concentrate a huge number of resources, and it also was noticed that big companies produce most of the innovations nowadays [61].

On the one hand, the firm innovation output positively depends on BoD's and CEO's low risk-aversion level, overconfidence, and innovativeness, but on the other hand, bankruptcy risk simultaneously increases. Also, it is noticeable that firms in which CEOs have a high propensity to innovate, provide more innovations, but only in innovative industries. Moreover, only extremely overconfident CEOs increase a firm's value through higher innovation output, while firms with moderately overconfident CEOs have lower stock volatility and bankruptcy risk. Large boards and the presence of external directors can mitigate the negative effects of CEO overconfidence. It seems that there is an optimal point corresponding with innovation efficiency: balance between BoD and CEO innovativeness (including different degrees of confidence, low risk-aversion, open-mindedness, proactivity, resistance, and creativity) and financial discretion. So, we can see that profit in innovative industries is analog of Schumpeter risk premium [1] and Knight payment for uncertainty [8].

Also, where is an interesting question that remains unresolved - who is more important for company innovativeness: the CEO or the board? According to my point of view, which is supported by Islam and Zein (2020) [61], the CEO plays a more important role in the innovation creation process than the board of directors, because the CEO is the manager and has a direct impact on business processes in the company when the board of directors - indirect. As a continuation of the study, it would be interesting to test predicted in Table 1 relationships on real data. There are also some limitations of the study. Firstly, we did not consider the full range of personal traits such as narcissism or short-termism, and characteristics like CEO power, etc. 
that also may be valuable for innovations prediction. Secondly, it seems that it is not possible to predict innovation impact on shareholders wealth based only on CEO and the board characteristics.

\section{References}

1. Śledzik K. Schumpeter's view on innovation and entrepreneurship. SSRN Electronic Journal. 2013. https://doi.org/10.2139/ssrn.2257783

2. Maclaurin W.R. The sequence from invention to innovation and its relation to economic growth. The Quarterly Journal of Economics. 1953;67(1):97-111. https://doi.org/10.2307/1884150

3. Nambisan S., Agarwal R., Tanniru M. Organizational mechanisms for enhancing user innovation in information technology. MIS quarterly, 1999;23(3):365-395. https://doi.org/10.2307/249468

4. Mohnen P., Mairesse J., Dagenais M. Innovativity: A comparison across seven European countries. Economics of Innovation and New Technology. 2006;15(4-5):391-413. https://doi. org/10.1080/10438590500512950

5. Singh S. Cultural differences in, and influences on, consumers' propensity to adopt innovations. International Marketing Review. 2006;23(2):173-191. https://doi.org/10.1108/02651330610660074

6. Hormiga E., Hancock C., Valls-Pasola J. The relationship between employee propensity to innovate and their decision to create a company. Management Decision. 2013;51(5):938-953. https:// doi.org/10.1108/MD-08-2012-0591

7. McGuirk H., Lenihan H., Hart M. Measuring the impact of innovative human capital on small firms' propensity to innovate. Research Policy. 2015;44(4):965-976. https://doi.org/10.1016/j. respol.2014.11.008

8. Knight F.H. Risk, uncertainty and profit. Boston, New York: Houghton, Mifflin Co.; 1921. 388 p.

9. Sunder J., Sunder S.V., Zhang J. Pilot CEOs and corporate innovation. Journal of Financial Economics. 2017;123(1):209-224. https://doi.org/10.1016/j. jifineco.2016.11.002

10. Allemand I., Brullebaut B., Galia F., Zenou E. Which board members when you innovate? Board selection as a strategic change for innovation. Strategic Change. 2017;26(4):311-322. https://doi.org/10.1002/jsc.2133

11. Schweizer T.S. The psychology of novelty-seeking, creativity and innovation: Neurocognitive aspects within a work-psychological perspective. Creativity and Innovation Management. 2006;15(2):164-172. https://doi.org/10.1111/j.1467-8691.2006.00383.x
12. Benjamin J., Li L., Patterson C., Greenberg B.D., Murphy D.L., Hamer D.H. Population and familial association between the D4 dopamine receptor gene and measures of Novelty Seeking. Nature Genetics. 1996;12(1):81-84. https://doi.org/10.1038/ng0196-81

13. Ebstein R.P., Novick O., Umansky R., Priel B., Osher Y., Blaine D., Belmaker R.H. et al. Dopamine D4 receptor (D4DR) exon III polymorphism associated with the human personality trait of novelty seeking. Nature Genetics. 1996;12(1):78-80. https://doi. org/10.1038/ng0196-78

14. Prolo P., Licinio J. DRD4 and novelty seeking. In: Benjamin J., Ebstein R.P., Belmaker R.H., eds. Molecular genetics and the human personality. Washington, DC: American Psychiatric Association Publ.; 2002:91-107.

15. Cloninger C.R., Svrakic D.M., Przybeck T.R. A psychobiological model of temperament and character. Archives of General Psychiatry. 1993;50(12):975-990. https://doi.org/10.1001/ archpsyc.1993.01820240059008

16. Zuckerman M., Eysenck S.B., Eysenck H.J. Sensation seeking in England and America: Cross-cultural, age, and sex comparisons. Journal of Consulting and Clinical Psychology. 1978;46(1):139-149. https://doi. org/10.1037//0022-006x.46.1.139

17. Zuckerman M. Behavioral expressions and biosocial bases of sensation seeking. Cambridge, New York: Cambridge University Press; 1994. 463 p.

18. Zuckerman M., Kuhlman D.M. Personality and risk-taking: Common bisocial factors. Journal of Personality. 2000;68(6):999-1029. https://doi. org/10.1111/1467-6494.00124

19. Zuckerman M. Sensation seeking. In: The Corsini encyclopedia of psychology. Hoboken, NJ: John Wiley \& Sons, Inc.; 2010:1-4.

20. Yagolkovskiy S. Relationships among individual-level correlates of innovation. International Journal of Innovation Science. 2020;11(2):196-207. https://doi. org/10.1108/IJIS-12-2017-0133

21. Martindale C. Biological bases of creativity. In: Sternberg R.J., ed. Handbook of creativity. Cambridge, New York: Cambridge University Press; 1999:137-152.

22. Mednick S. The associative basis of the creative process. Psychological Review. 1962;69(3):220-232. https://doi.org/10.1037/h0048850

23. Carson S.H., Peterson J.B., Higgins D.M. Decreased latent inhibition is associated with increased creative achievement in high-functioning individuals. Journal of Personality and Social Psychology. 2003;85(3):499506. https://doi.org/10.1037/0022-3514.85.3.499. 
24. West M.A. Sparkling fountains or stagnant ponds: An integrative model of creativity and innovation implementation in work groups. Applied Psychology. 2002;51(3):355-387. https://doi.org/10.1111/14640597.00951

25. Cropley D.H., Kaufman J.C., Cropley A.J. Measuring creativity for innovation management. Journal of Technology Management \& Innovation. 2011;6(3):13-30. https://doi.org/10.4067/S071827242011000300002

26. Frishammar J., Åke Hörte S. The role of market orientation and entrepreneurial orientation for new product development performance in manufacturing firms. Technology Analysis \& Strategic Management. 2007;19(6):765-788. https://doi. org/10.1080/09537320701711231

27. Laursen K., Masciarelli F., Prencipe A. Regions matter: How localized social capital affects innovation and external knowledge acquisition. Organization Science. 2012;23(1):177-193. https://doi. org/10.2307/41429024

28. Garcia R., Calantone R. A critical look at technological innovation typology and innovativeness terminology: A literature review. Journal of Product Innovation Management. 2002;19(2):110-132. https:// doi.org/10.1016/S0737-6782(01)00132-1

29. Li M. Diversity of board interlocks and the impact on technological exploration: A longitudinal study. Journal of Product Innovation Management. 2019;36(4):490-512. https://doi.org/10.1111/ jpim. 12488

30. Singh J., Fleming L. Lone inventors as sources of breakthroughs: Myth or reality? Management Science. 2010; 56(1):41-56. https://doi.org/10.1287/ mnsc. 1090.1072

31. Coskun H., Paulus P.B., Brown V., Sherwood J.J. Cognitive stimulation and problem presentation in idea-generating groups. Group Dynamics: Theory, Research, and Practice. 2000;4(4):307-329. https://doi. org/10.1037/1089-2699.4.4.307

32. Damanpour F. Organizational complexity and innovation: Developing and testing multiple contingency models. Management Science. 1996;42(5):693-716. https://doi.org/10.1287/ mnsc. 42.5 .693

33. Damanpour F., Evan W.M. Organizational innovation and performance: The problem of "organizational lag”. Administrative Science Quarterly. 1984;29(3):392402. https://doi.org/10.2307/2393031

34. Rogers E.M. Diffusion of innovations. New York: Simon and Schuster; 2010. 518 p.

35. Zaltman G., Duncan R., Holbek J. Innovations and organizations. New York: John Wiley \& Sons, Inc.; 1973. $212 \mathrm{p}$.
36. Damanpour F. An integration of research findings of effects of firm size and market competition on product and process innovations. British Journal of Management. 2010;21(4):996-1010. https:/doi. org/10.1111/j.1467-8551.2009.00628.x

37. Snihur Y., Wiklund J. Searching for innovation: Product, process, and business model innovations and search behavior in established firms. Long Range Planning. 2019;52(3):305-325. https://doi. org/10.1016/j.lrp.2018.05.003

38. Dewar R.D., Dutton J.E. The adoption of radical and incremental innovations: An empirical analysis. Management Science. 1986;32(11):1422-1433. https:// doi.org/10.1287/mnsc.32.11.1422

39. Van de Ven A.H., Chu Y.H. A psychometric assessment of the Minnesota innovation survey. In: Van de Ven A.H., Angle H.L., Poole M.S., eds. Research on the management of innovation: The Minnesota studies. Oxford, New York: Oxford University Press; 2000:55-103.

40. Ettlie J.E., Bridges W.P., O’keefe R.D. Organization strategy and structural differences for radical versus incremental innovation. Management Science. 1984;30(6):682-695. https://doi.org/10.1287/ mnsc.30.6.682

41. Wong Y.-J., Lee C.-Y., Chang S.-C. CEO overconfidence and ambidextrous innovation. Journal of Leadership \& Organizational Studies. 2017;24(3):414-430. https://doi. org/10.1177/1548051817692329

42. Salas Vallina A., Moreno-Luzon M.D., FerrerFranco A. The individual side of ambidexterity: Do inspirational leaders and organizational learning resolve the exploitation-exploration dilemma? Employee Relations. 2019;41(3):592-613. https://doi. org/10.1108/ER-02-2018-0050

43. Utterback J.M., Abernathy W.J. A dynamic model of process and product innovation. Omega. 1975;3(6):639-656. https://doi.org/10.1016/03050483(75)90068-7

44. Laursen K., Salter A. Open for innovation: The role of openness in explaining innovation performance among UK manufacturing firms. Strategic Management Journal. 2006;27(2):131-150. https://doi. org/10.1002/smj.507

45. Reichstein T., Salter A. Investigating the sources of process innovation among UK manufacturing firms. Industrial and Corporate Change. 2006;15(4):653-682. https://doi.org/10.1093/icc/dt1014

46. Leiponen A., Helfat C.E. Innovation objectives, knowledge sources, and the benefits of breadth. Strategic Management Journal. 2010;31(2):224-236. https://doi.org/10.1002/smj.807 
47. Terjesen S., Patel P.C. In search of process innovations: The role of search depth, search breadth, and the industry environment. Journal of Management. 2017;43(5):1421-1446. https://doi. org/10.1177/0149206315575710

48. Amit R., Zott C. Creating value through business model innovation. MIT Sloan Management Review. 2012;53(3):41-49. URL: http://aproaingenieria.com/ intranet/uploads/creating-value-through-businessmodel-innovation.pdf

49. Johnson M.W., Christensen C.M., Kagermann H. Reinventing your business model. Harvard Business Review. 2008;86(12):57-68. URL: http://radio. shabanali.com/reinventing-your-business-model.pdf

50. Crossan M.M., Apaydin M. A multi-dimensional framework of organizational innovation: A systematic review of the literature. Journal of Management Studies. 2010;47(6):1154-1191. https:// doi.org/10.1111/j.1467-6486.2009.00880.x

51. Foss N.J., Saebi T. Fifteen years of research on business model innovation: How far have we come, and where should we go? Journal of Management. 2017;43(1):200-227. https://doi. org/10.1177/0149206316675927

52. Chan L.K., Lakonishok J., Sougiannis T. The stock market valuation of research and development expenditures. The Journal of Finance. 2001;56(6):2431-2456. https://doi.org/10.1111/00221082.00411

53. Hirshleifer D., Hsu P.-H., Li D. Innovative efficiency and stock returns. Journal of Financial Economics. 2013;107(3):632-654. https://doi.org/10.1016/j. jineco.2012.09.011

54. Asensio-López D., Cabeza-García L., GonzálezÁlvarez N. Corporate governance and innovation: A theoretical review. European Journal of Management and Business Economics. 2019;28(3):266-284. https:// doi.org/10.1108/EJMBE-05-2018-0056

55. Bravo F., Reguera-Alvarado N. The effect of board of directors on R\&D intensity: Board tenure and multiple directorships. R\&D Management. 2017;47(5):701-714. https://doi.org/10.1111/ radm. 12260

56. Jaisinghani $\mathrm{D}$. Impact of $\mathrm{R} \& \mathrm{D}$ on profitability in the pharma sector: An empirical study from India. Journal of Asia Business Studies. 2016;10(2):194-210. https://doi.org/10.1108/JABS-03-2015-0031

57. International Financial Reporting Standards. International Accounting Standard 48 (IAS 48). 2004. URL: https://www.ifrs.org/issued-standards/list-ofstandards/ias-38-intangible-assets/

58. Roberts P.W. Product innovation, product-market competition and persistent profitability in the US pharmaceutical industry. Strategic Management Journal. 1999;20(7):655-670. https://doi.org/10.1002/ (SICI) 1097-0266(199907)20:7<655::AIDSMJ44>3.0.CO;2-P

59. Fritsch M. Measuring the quality of regional innovation systems: A knowledge production function approach. International Regional Science Review. 2002;25(1):86-101. https://doi. org/10.1177/016001702762039394

60. Hirshleifer D., Low A., Teoh S.H. Are overconfident CEOs better innovators? The Journal of Finance. 2012;67(4):1457-1498. https://doi.org/10.1111/j.15406261.2012.01753.x

61. Islam E., Zein J. Inventor CEOs. Journal of Financial Economics. 2020;135(2):505-527. https://doi. org/10.1016/j.jfineco.2019.06.009

62. Van Zeebroeck N. The puzzle of patent value indicators. Economics of Innovation and New Technology. 2011;20(1):33-62. https://doi. org/10.1080/10438590903038256

63. Lev B., Sarath B., Sougiannis T. R\&D reporting biases and their consequences. Contemporary Accounting Research. 2005;22(4):977-1026. URL: http://citeseerx. ist.psu.edu/viewdoc/download?doi=10.1.1.168.1168\& rep=rep $1 \&$ type $=$ pdf

64. Ballester M., Garcia-Ayuso M., Livnat J. The economic value of the R\&D intangible asset. European Accounting Review. 2003;12(4):605-633. https://doi.org/10.1080/09638180310001628437

65. Bernstein J.I., Mamuneas T.P. R\&D depreciation, stocks, user costs and productivity growth for US R\&D intensive industries. Structural Change and Economic Dynamics. 2006;17(1):70-98. https://doi. org/10.1016/j.strueco.2005.04.003

66. Hall B.H. The financing of innovation. In: Shane S., ed. The handbook of technology and innovation management. Chichester: John Wiley \& Sons Ltd; 2009:409-430.

67. Li W.C., Hall B.H. Depreciation of business R\&D capital. Review of Income and Wealth. 2020;66(1):161180. https://doi.org/10.1111/roiw.12380

68. Oswald D.R., Zarowin P. Capitalization of R\&D and the informativeness of stock prices. European Accounting Review. 2007;16(4):703-726. https://doi. org/10.1080/09638180701706815

69. Cohen L., Diether K., Malloy C. Misvaluing innovation. The Review of Financial Studies. 2013;26(3):635-666. https://doi.org/10.1093/rfs/ hhs 183

70. Balsmeier B., Fleming L., Manso G. Independent boards and innovation. Journal of Financial Economics. 2017;123(3):536-557. https://doi. org/10.1016/j.jfineco.2016.12.005 
71. Shapiro D., Tang Y., Wang M., Zhang W. The effects of corporate governance and ownership on the innovation performance of Chinese SMEs. Journal of Chinese Economic and Business Studies. 2015;13(4):311-335. https://doi.org/10.1080/1476528 4.2015 .1090267

72. Balsmeier B., Buchwald A., Stiebale J. Outside directors on the board and innovative firm performance. Research Policy. 2014;43(10):1800-1815. https://doi.org/10.1016/j.respol.2014.06.003

73. Helmers C., Patnam M., Rau P.R. Do board interlocks increase innovation? Evidence from a corporate governance reform in India. Journal of Banking \& Finance. 2017;80:51-70. https://doi.org/10.1016/j. jbankfin.2017.04.001

74. Waheed A., Malik Q.A. Board characteristics, ownership concentration and firms' performance: A contingent theoretical based approach. South Asian Journal of Business Studies. 2019;8(2):146-165. https:// doi.org/10.1108/SAJBS-03-2018-0031

75. Yoo T., Sung T. How outside directors facilitate corporate R\&D investment? Evidence from large Korean firms. Journal of Business Research. 2015;68(6):1251-1260. https://doi.org/10.1016/j. jbusres.2014.11.005

76. Rossi M., Galasso S., Capasso A. Women do it better: An investigation on the association between gender diversity in board of directors and the financial performance. International Journal of Economics and Financial Issues. 2017;7(6):41-50. URL: https://www. proquest.com/openview/05decb77ealc01a157a8a17e aa6fb875/1 ?pq-origsite $=$ gscholar $\& \mathrm{cbl}=816338$

77. Fehr-Duda H., De Gennaro M., Schubert R. Gender, financial risk, and probability weights. Theory and Decision. 2006;60(2-3):283-313. https://doi. org/10.1007/s11238-005-4590-0

78. Adams R.B., Ragunathan V. Lehman sisters. SSRN Electronic Journal. 2015. http://dx.doi.org/10.2139/ ssrn.2380036

79. Chen H.-L. Board characteristics and R\&D investment: Evidence from Taiwan's electronics industry. Advances in Management and Applied Economics. 2012;2(4):161-170. URL: https://citeseerx. ist.psu.edu/viewdoc/download?doi=10.1.1.1062.8123 \&rep $=$ rep $1 \&$ type $=$ pdf

80. Vafeas N. Board meeting frequency and firm performance. Journal of Financial Economics. 1999;53(1):113-142. https://doi.org/10.1016/S0304405X(99)00018-5

81. Ben-Amar W., Francoeur C., Hafsi T., Labelle R. What makes better boards? A closer look at diversity and ownership. British Journal of Management. 2013;24(1):85-101. https://doi.org/10.1111/j.14678551.2011.00789.x
82. Sun X., Li H., Ghosal V. Firm-level human capital and innovation: Evidence from China. China Economic Review. 2020;59:101388. https://doi.org/10.1016/j. chieco.2019.101388

83. Jermias J. The effects of corporate governance on the relationship between innovative efforts and performance. European Accounting Review. 2007;16(4):827-854. https://doi. org/10.1080/09638180701707045

84. Li M., Yang J. Effects of CEO duality and tenure on innovation. Journal of Strategy and Management. 2019;12(4):536-552. https://doi.org/10.1108/JSMA04-2019-0049

85. Bernile G., Bhagwat V., Rau P.R. What doesn't kill you will only make you more risk-loving: Early-life disasters and CEO behavior. The Journal of Finance. 2017;72(1):167-206. https://doi.org/10.1111/ jofi. 12432

86. Zuraik A., Kelly L. The role of CEO transformational leadership and innovation climate in exploration and exploitation. European Journal of Innovation Management. 2019;22(1):84-104. https://doi. org/10.1108/EJIM-10-2017-0142

87. Mukherjee A., Singh M., Žaldokas A. Do corporate taxes hinder innovation? Journal of Financial Economics. 2017;124(1):195-221. https://doi. org/10.1016/j.jfineco.2017.01.004

88. Bostan I., Mian G.M. Inventor chief executive officers and firm innovation. International Review of Finance. 2019;19(2):247-286. https://doi.org/10.1111/ irfi.12266

89. Barker V.L. III, Mueller G.C. CEO characteristics and firm R\&D spending. Management Science. 2002;48(6):782-801. https://doi.org/10.1287/ mnsc.48.6.782.187

90. Custódio C., Ferreira M.A., Matos P. Do general managerial skills spur innovation? Management Science. 2019;65(2):459-476. https://doi.org/10.1287/ mnsc. 2017.2828

91. Gottesman A.A., Morey M.R. Does a better education make for better managers? An empirical examination of CEO educational quality and firm performance. SSRN Electronic Journal. 2006. https:// doi.org/10.2139/ssrn.564443

92. Acemoglu D., Akcigit U., Celik M.A. Young, restless and creative: Openness to disruption and creative innovations. NBER Working Paper. 2014;(19894). URL: https://www.nber.org/system/files/working_ papers/w19894/w19894.pdf

93. Kandasamy N., Hardy B., Page L., Schaffner M., Graggaber J., Powlson A.S. et al. Cortisol shifts financial risk preferences. PNAS. 2014;111(9):36083613. https://doi.org/10.1073/pnas.1317908111 
94. Eisenman R. Creativity, birth order, and risk taking. Bulletin of the Psychonomic Society. 1987;25(2):87-88. https://doi.org/10.3758/BF03330292

95. Tyagi V., Hanoch Y., Hall S.D., Runco M., Denham S.L. The risky side of creativity: Domain specific risk taking in creative individuals. Frontiers in Psychology. 2017;8:145. https://doi.org/10.3389/fpsyg.2017.00145

96. Bénabou R., Tirole J. Intrinsic and extrinsic motivation. The Review of Economic Studies. 2003;70(3):489-520. https://doi.org/10.1111/1467937X.00253

97. Dewett T. Linking intrinsic motivation, risk taking, and employee creativity in an R\&D environment. R\&D Management. 2007;37(3):197-208. https://doi. org/10.1111/j.1467-9310.2007.00469.x

98. Loch C.H. Creativity and risk taking aren't rational: Behavioral operations in MOT. Production and Operations Management. 2017;26(4):591-604. https:// doi.org/10.1111/poms.12666

99. Shen W., Hommel B., Yuan Y., Chang L., Zhang W. Risk-taking and creativity: Convergent, but not divergent thinking is better in low-risk takers. Creativity Research Journal. 2018;30(2):224-231. 10.1080/10400419.2018.1446852

100. López-Bonilla J.M., López-Bonilla L.M. Sensationseeking profiles and personal innovativeness in information technology. Social Science Computer Review. 2012;30(4):434-447. https://doi. org/10.1177/0894439311427246

101. Grinblatt M., Keloharju M. Sensation seeking, overconfidence, and trading activity. The Journal of Finance. 2009;64(2):549-578. https://doi.org/10.1111/ j.1540-6261.2009.01443.x

102. Fischer P., Kubitzki J., Guter S., Frey D. Virtual driving and risk taking: Do racing games increase risk-taking cognitions, affect, and behaviors? Journal of Experimental Psychology: Applied. 2007;13(1):2231. https://doi.org/10.1037/1076-898X.13.1.22

103. Self D.R., De Vries Henry E., Findley C.S., Reilly E. Thrill seeking: The type T personality and extreme sports. International Journal of Sport Management and Marketing. 2007;2(1-2):175-190. https://doi. org/10.1504/IJSMM.2007.011397

104. Brymer E. Risk taking in extreme sports: A phenomenological perspective. Annals of Leisure Research. 2010;13(1-2):218-238. https://doi.org/10.10 $80 / 11745398.2010 .9686845$

105. Bernile G., Bhagwat V., Rau P.R. What doesn't kill you will only make you more risk-loving: Early-life disasters and CEO behavior. The Journal of Finance. 2017;72(1):167-206. https://doi.org/10.1111/ jofi. 12432

106. Serfling M.A. CEO age and the riskiness of corporate policies. Journal of Corporate Finance. 2014;25:251273. https://doi.org/10.1016/j.jcorpfin.2013.12.013

107. Brooks C., Sangiorgi I., Hillenbrand C., Money $\mathrm{K}$. Why are older investors less willing to take financial risks? International Review of Financial Analysis. 2018;56:52-72. https://doi.org/10.1016/j. irfa.2017.12.008

108. Frijns B., Gilbert A., Lehnert T., Tourani-Rad A. Uncertainty avoidance, risk tolerance and corporate takeover decisions. Journal of Banking \& Finance. 2013;37(7):2457-2471. https://doi.org/10.1016/j. jbankfin.2013.02.010

109. Griffin D., Tversky A. The weighing of evidence and the determinants of confidence. Cognitive Psychology. 1992;24(3):411-435. https://doi.org/10.1016/00100285(92)90013-R

110. Malmendier U., Tate G. CEO overconfidence and corporate investment. The Journal of Finance. 2005;60(6):2661-2700. https://doi.org/10.1111/j.15406261.2005.00813.x

111. Malmendier U., Tate G. Who makes acquisitions? CEO overconfidence and the market's reaction. Journal of Financial Economics. 2008;89(1):20-43. https://doi.org/10.1016/j.jfineco.2007.07.002

112. Galasso A., Simcoe T.S. CEO overconfidence and innovation. Management Science. 2011;57(8):14691484. https://doi.org/10.1287/mnsc.1110.1374

113. Chang X., Chen Y., Wang S.Q., Zhang K., Zhang W. Credit default swaps and corporate innovation. Journal of Financial Economics. 2019;134(2):474-500. https://doi.org/10.1016/j.jfineco.2017.12.012

114. Chen C.X., Gores T., Nasev J. Managerial overconfidence and cost stickiness. SSRN Electronic Journal. 2013. https://doi.org/10.2139/ssrn.2208622

115. Deshmukh S., Goel A.M., Howe K.M. CEO overconfidence and dividend policy. Journal of Financial Intermediation. 2013;22(3):440-463. https:// doi.org/10.1016/j.jfi.2013.02.003

116. Kolasinski A.C., Li X. Can strong boards and trading their own firm's stock help CEOs make better decisions? Evidence from acquisitions by overconfident CEOs. Journal of Financial and Quantitative Analysis. 2013;48(4):1173-1206. https:// doi.org/10.1017/S0022109013000392

117. Hall B.H., Jaffe A., Trajtenberg M. Market value and patent citations. RAND Journal of Economics. 2005;36(1):16-38. URL: https://eml.berkeley. edu// bhhall/papers/HallJaffeTrajtenberg_RJEjan04. pdf

118. Kim J.-B., Wang Z., Zhang L. CEO overconfidence and stock price crash risk. Contemporary Accounting Research. 2016;33(4):1720-1749. https://doi. org/10.1111/1911-3846.12217 
119. Leng J., Ozkan A., Trzeciakiewicz A. CEO overconfidence and the probability of corporate failure: Evidence from the UK. SSRN Electronic Journal. 2018. http://dx.doi.org/10.2139/ssrn.3184199

120. Li J., Tang Y.I. CEO hubris and firm risk taking in China: The moderating role of managerial discretion. Academy of Management Journal. 2010;53(1):45-68. https://doi.org/10.5465/amj.2010.48036912

121. Nakano M., Nguyen P. Board size and corporate risk taking: Further evidence from Japan. Corporate Governance: An International Review. 2012;20(4):369-387. https://doi.org/10.1111/j.14678683.2012.00924.x

122. Banerjee S., Humphery-Jenner M., Nanda V. Restraining overconfident CEOs through improved governance: Evidence from the Sarbanes-Oxley Act. The Review of Financial Studies. 2015;28(10):28122858. https://doi.org/10.1093/rfs/hhv034
123. O'Connor M.A. The Enron board: The perils of groupthink. University of Cincinnati Law Review. 2002;71:1233. URL: https://heinonline. org/HOL/LandingPage?handle=hein.journals/ ucinlr71\&div $=55 \&$ id $=$ \&page $=$

124. Graham J.R., Harvey C.R., Puri M. Managerial attitudes and corporate actions. Journal of Financial Economics. 2013;109(1):103-121. https://doi. org/10.1016/j.jfineco.2013.01.010

125. Baldenius T., Melumad N., Meng X. Board composition and CEO power. Journal of Financial Economics. 2014;112(1):53-68. https://doi. org/10.1016/j.jfineco.2013.10.004

126. Story V.M., Boso N., Cadogan J.W. The form of relationship between firm-level product innovativeness and new product performance in developed and emerging markets. Journal of Product Innovation Management. 2015;32(1):45-64. https:// doi.org/10.1111/jpim.12180

Contribution of the authors: the authors contributed equally to this article.

The authors declare no conflicts of interests.

The article was submitted 06.11.2021; approved after reviewing 08.11.2021; accepted for publication 14.11.2021. 